\title{
Pleasure in reading tradition
}

\author{
Mirjana Lozanovska
}

\begin{abstract}
Introduction
The notion of architecture as static, physical and inanimate has been challenged several times in its history through, for instance, theoretical enquiry into the ways in which human movements and activities, the less tangible movements of heat and air, and the familiar paths of sunlight can reconfigure both its sensibility and meanings. This paper explores the performative function of architectural space and is based on my observation of the atmosphere produced by activities taking place in the Byzantine church in Zavoj, a mountain village in the Republic of Macedonia, during the Day of the Holy Mother celebrated annually on August 28. During my field-work, I noted the priest's liturgical practices, scripts, the ceremonial choreography of the congregation, prayer, individual iterations of ritual, as well as candlelight, heat, and scent. But such observations present a problem for architectural representation, because it is not easy to delineate the volume and geometry of the church from the bodily activity and the hazy air from the surface fresco treatment of the walls. How, then, can architecture be thought from the position of an observer?
\end{abstract}

Theories on atmosphere focus on the in-between, as neither objective nor subjective. Gernot Böhme, for example, refers to the intersubjective qualities of atmospheres and their importance in the 'aesthetic scenes' characteristic of the English garden, which he regards as an historical paradigm for the production of atmospheres (Böhme 2014, p 95 in this volume). More recently, the formal, functional and even phenomenological frameworks of architectural thinking have shifted towards notions of theatricality and stage setting. Böhme's strong critical perspective implies a link between the desire to experience and to enter an atmosphere and an obligation to perform the commodity, not just to view or purchase it (Böhme 2013). In contrast, much atmosphere theory in architecture wants to understand experience beyond signs and is generally positioned against theories of signs and language (Moravansky 2010: 61). In this paper, the full scene of the church interior as atmosphere will be interpreted in relation to the role of signification.

Michel de Certeau's concept of the spatial story outlines how the temporal dimension of space is inscribed by language. Interaction of narrative, story, and words transfers space from an abstract condition into a space through which human subjectivity is formed. Henri Lefebvre's in The Production of Space (1991) critiques and uses language to address the complicated relations between subject and object, spatiality and sensuality. In a similar vein, to gain an understanding of architectural atmosphere, I will explore the role of traditional Western architectural representation, and the difficulties its conventions have in communicating the mixture that constitutes the church interior at Zavoj. Through an 'archi-textual methodology', I will build an inventory, using on-site methodologies combining measured drawings (plans, sections), sketches (details, artefacts), and visual documentation (photographs, elevations). These documents are related to recordings of conversations, (village) tales and myths, (village) histories, statistics and other data (Lozanovska 2004). Responding to Certeau's (1984) critique of the map or plan, the focus is on how 'reading' can interpret, revise and rewrite meaning and experience.

'Texts', visual or written, house unconscious dimensions of meaning that we enter as readers. Inspired by Alfred Lorenzer's method and aim of scenic understanding (see Olesen \& Weber 2013: 33), ${ }^{1}$ the argument constructs a dual scene including both the 'architectural scene' inside the church and the parameters of looking at that scene. As the signifier of an otherness to architecture, the vernacular provides a position for the observation and interpretation of architecture. Focusing 
on the performative dimension of architecture and, in particular, the annual ceremony for the patron saint of the village, the Holy Mother, on August 28, this paper is a part of a longitudinal study of the village of Zavoj and contributes to the examination of architectural meaning as continually re-enacted and revised through the use, location, movement and ritual of bodies in space.

In The pleasure of the text, Roland Barthes (1975) proposes that, when we read, our bodies extend beyond the field of the text into a landscape of memories, associations and pleasures, and that good writing enables and entices the reader into this embodied world. Barthes refers to the reader as a body-subject who might be moved by resonant and affective words beyond merely absorbing information, or reacting to it cerebrally. Through reading, a situation between the reader and the author arises in which the work is reconfigured.

This kind of reading is important for a method by which to interpret field-work documentation. I was strongly affected by my observations of the ritual, activity and ceremony in the Zavoj church, starting on August 28, 1988 during the Day of the Holy Mother, and repeated over a series of field trips up to $2013 .^{2}$ Subsequently, it seemed important to preserve some of the impressions of the interior scene; these impressions contrasted and complemented the tendency of architectural practice and education towards measurement and measured documentation, and the execution of drafted plans and elevations. From observation, interviews, recordings of stories, histories, and memoirs, I developed a critico-creative, narrative text (see Lozanovska 2006). Its focus is on the interior of the church, and the women's rituals during the 1988 festivity of the Day of the Holy Mother. $^{3}$

On arrival at the church, the women and men part ways. The women walk through the side door into the church building. The men merge with other groups of men outside in the church ground, away from the church building, many of them leaning on the fence which marks the perimeter of the church ground.

This critico-creative text is outlined in another paper; I use it here to set a scene of atmospheric architectural sensibility, and as literary device to provoke alternative interpretations of the relation between architecture and atmosphere. It contrasts the clarity of volume and geometry, and the latter's dominant tradition of linear representation in plan and elevation. It is also a citation or a reminder of the experiential basis of observation and the observer's (and author's) ontological immersion in the atmosphere of the interior of the Zavoj church (see Olesen \& Weber 2013).

The descriptions of bodily movement and temporality produce an effect of sensuality here that gives rise to several theoretical concerns. Firstly, who is moved? The worshippers at the Church of the Holy Mother performed well-rehearsed rituals (and may have had mundane things on their mind), rather than being spiritually immersed in their movements. In order to examine this question, the'scene' of the church interior is read through Byzantine aesthetics and tradition (Ouspensky and Lossky 1952; Demus 1955; Mathews 1999). ${ }^{4}$ Judith Butler's theory of the performative body is used to examine the bodies inside the church, and the conflict between unconscious desire and conscious values, not in order to decode their meanings, but to argue that corporeal movement is mediated iteratively through language. Secondly, what meanings are mobilised by particular forms of representation, like photographs, drawings, and textual description? Do these operate as habitual props to architectural theory, or can they, severally and together, serve a critical role in the articulation of a theory on movement and architecture? Thirdly, Kaja Silverman's theory, that the visual can act as a guide to the subconscious states of a collective social present (1996), adds another dimension to Lorenzer's approach: the 're-use' of on-site observation in the representation of the environment then becomes a way of 'looking again'. 


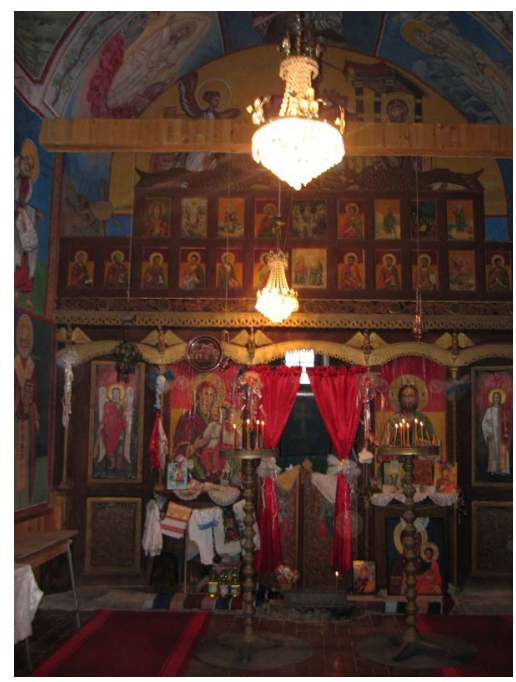

Fig. 1 The richly ornamented Byzantine interior, east wall and iconostas, with offerings, in the Church of the Holy Mother, Zavoj, Republic of Macedonia. [Photo: Author, 2005]

\section{Who is moved?: Byzantine context, local traditions and the body}

Not only is the icon a "theological mark" (Serafimova 1995: 109-110) - most importantly, when "icons are kissed" an embodied relationship arises (Aipatov 1978: 7). In contrast to the distant, visual approach to art-as-image, icons are, to the faithful and to the iconographer, acts of prayer, and icon painting is considered as liturgy (iconography registers both the icons on the iconostas and the fresco paintings).

Inside the church, women light candles, pray, bow towards the altar, kiss the icons, place flowers beside them, and gesture the sign of the cross. In 1989, they perform these rituals individually, solemnly and in silence for about thirty minutes. These are familiar customs of Christian belief. The women also place specially prepared foods on a large table to one side of the church interior. Along the iconostas, money, men's white shirts, socks and white towels are placed on a string. This ritual may be particular to the vernacular churches in this region. It is like washing on a line, and it reminds me of dressing and housekeeping tasks.

Byzantine tradition is, according to Aneta Serafimova, a "spiritually aesthetic act" (1995: 110). Its liturgy, enacted through ritual, iconography, scent and music, is both embodied and aesthetic (Lossky 1952: 14). Vernacular church interiors in the Byzantine tradition in this region of Macedonia follow some basic rules concerning the hierarchical composition of icons and the centralised-basilica geometry. In the intensely colourful interior of the Church of the Holy Mother, Zavoj, candlelight that illuminates the surfaces is reflected in the gold halos of the icons (see Figure 2). This church was built in 1934, and the most recent repainting of the interior iconography was executed between 1988 and 2007. By examining the particularities of local tradition and ritual manifest in the church interior, this section explores the question of 'who is moved'.

Butler argues, in contrast to prevailing theological interpretation of acts of tradition and ritual, that the performative body produces 'normativity' through the iterations of socially and culturally appropriate bodily gestures, activities and attitudes (2004; 2009), which are evident in the rituals performed in this church. Ritual, in this context, is not formally learnt or rehearsed, or directed by prior reading of scripture or biblical texts. Rather, it is a corporeal practice of a tradition in which the body imitates actions it must appropriate in order to achieve recognition in the community. 
While bodies are always inscribed with familiar social categories (gender, age, wealth), they are produced as differentiated bodies only through practice. Butler's theory emphasises that the body is not static but repeatedly recoded through iteration and practice. The girl-child, in her traditional dress, imitates and performs the ritual of the woman-body, in order to become a normative gendered subject in her community (Fig. 2).
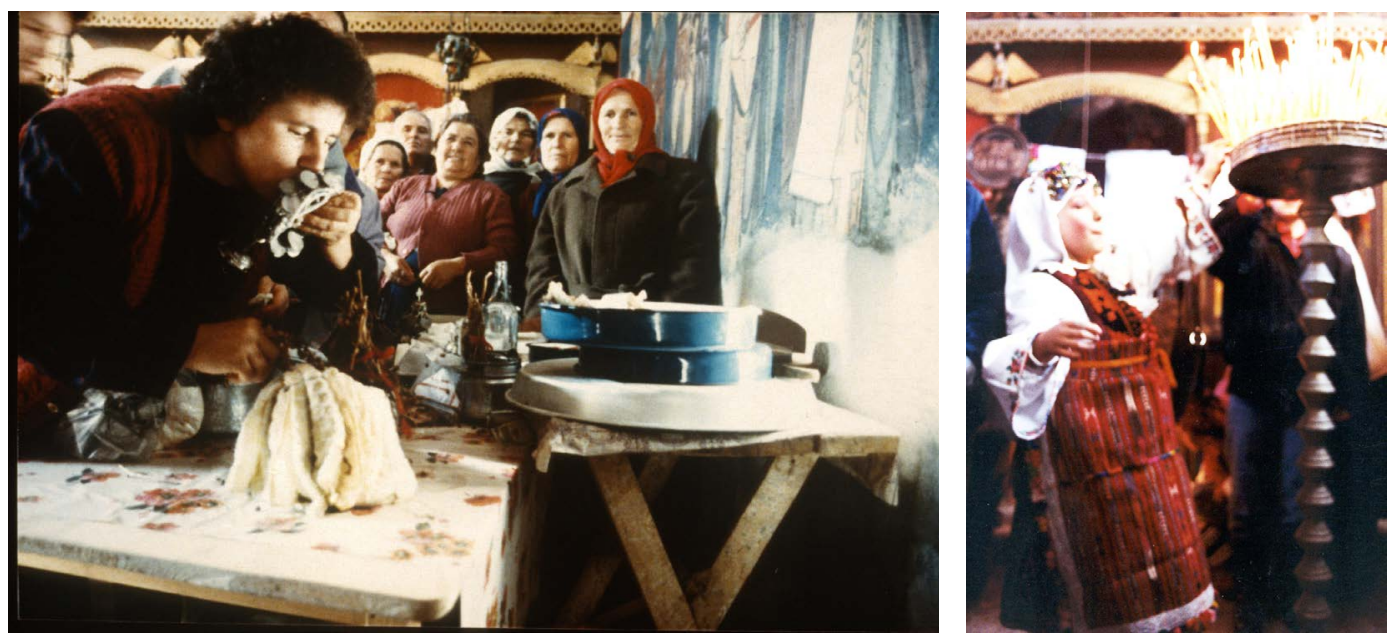

Fig. 2 Rituals in the Church of the Holy Mother, Zavoj, Republic of Macedonia. [Photo: Author, 1988]

Given the societal forces producing normativity, is it possible to be moved beyond the boundaries of normative subjectivity in this scene of traditional practice, and were individual members moved in this way in my presence? Both descriptive text and photography provide ways of exploring this question. The photographs' temporal specificity, extracted and abstracted from time and history, aspires towards capturing the real or imaginary condition rather than the symbolic field of consciousness and coded realities (Silverman 1996). Physicist Étienne-Jules Marey’s sequences and still photography, for instance, indicate this other sensibility of being moved. In Zavoj, the photograph of the girl-child lighting a candle conveys a sense of levitation or suspension: the girl has to rise above her own height, raising herself on her toes, in order to light the candle. This gesture produces a tension between realism (rise on toes) and the real (elevated spiritually), and illustrates Butler's point that each iteration has the potential for slippage and appropriation. The photograph plays the role of Lorenzer's concept of social imagination as it invites the reader to look again and to note that her traditional dress is not only linked to a gendered subject, but empathetically linked to the interior aesthetics and collective culture. In the same way, aspects of dressing, described above, can be alternately perceived as domestic effect and sensual affect of both the church as a body and the body of Christ.

In combination with those of the women, the liturgical practices of the priest create an architectural space of fluidity, excess and ambiguity (in the 1988 liturgy, for instance, a young enthusiastic priest's voice echoes off the interior surfaces for over an hour). Moving along the east-west axis of the church building, the priest blesses the congregation with basil holy water; smoky, scented air wafts from the incense burner. The movement of air, the floating scents of flowers and foods, metallic ringing sounds, the temperatures of candles burning, bodies breathing and brushing against iconographic saints, and lips touching painterly surfaces - all whirl in and around the structural timber beams of the architecture, curl their way through the carvings of the altar screen, hover in the recesses of the ceiling, precipitate at the architraves, and lightly hang, like an invisible veil, over the medieval clothing of the frescoed saints (Lozanovska 2006:323-330). 
Language, mediating the socio-material structure of society (Olesen \& Weber 2013: 28), can bring attention to the role of the material aspects of the interior of the church. The scene not only refers to the subject, or the subjective, but to the co-production between subject and object in the enveloping atmosphere. The fusion between atmospheric affects, ornamentation, and geometric architectural space challenges theories of art and architecture that promote a separation between object, form, and structure from interior, surface, colour and ornamentation. Likewise, Spiro Kostof (1995) proposes an approach to architecture and its understanding that emphasizes ritual and setting, thereby opening the discipline towards a layered sensibility of interior space. Gottfried Semper argued that architecture is constituted by the feminine domestic arts, such as hanging cloths, carpets and other woven interior wall dividers; walls are surfaces turned structure. Architectural space is, above all, inscribed with meaning, rather than abstract three-dimensional object or volume (1989: 104). Thus, the Byzantine practice of renewing and repainting the icon paintings of the frescoed walls suggests that architecture is an operative (rather than static) tradition. ${ }^{5}$ In this context, then, a division between tangible (architecture, building) and intangible elements (customs, songs, prayer) is problematic. (Fig. 3)

Studies of Byzantine space have repeatedly emphasised its simultaneously two- and three-dimensional character (Ouspensky and Lossky 1989; Serafimova 1989) ${ }^{6}$ and the central role of the pictorial programme - it could be argued that the Byzantine Church is constructed through the picture-space of the icons (Mathews 1999: 114). The integral and non-separable union of walls and frescoes governs the perception of the interior, and illustrates a content-oriented aesthetic organisation. The walls' surfaces are the site for theological inscription; Byzantine aesthetic is as much about message and narrative as it is about colour, luminosity and affect. Saintly figures and biblical scenes follow a hierarchical composition, and the meaning of the icon (whether on wood panels or as frescoed walls) is distributed across the surfaces of the picture plane (in contrast to Western traditions that aim for depth and perspective). Thus, the Byzantine pictorial idea of volume makes explicit that two-dimensional inscription tied to narrative and scripture cannot be substituted by three-dimensional volume. Iconography defines the atmosphere in the church interior, and to preserve the intended meaning, any penetration of the plane of the panel is avoided.

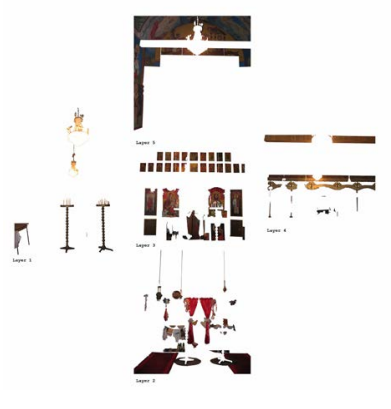

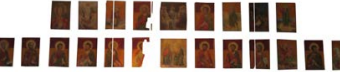

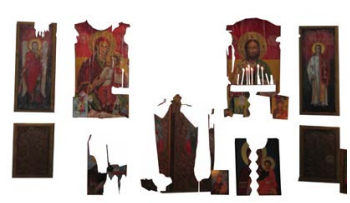

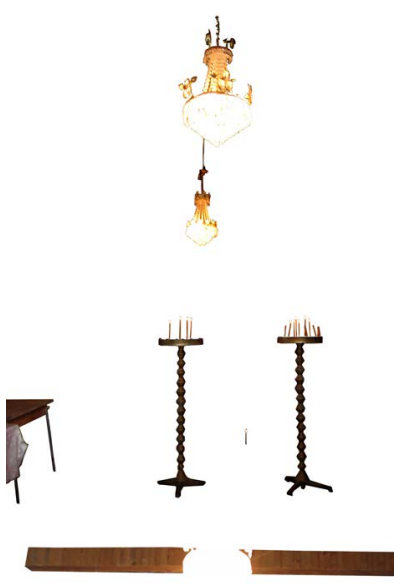

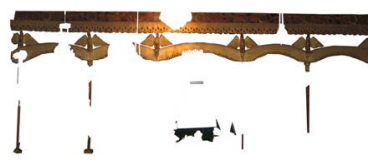

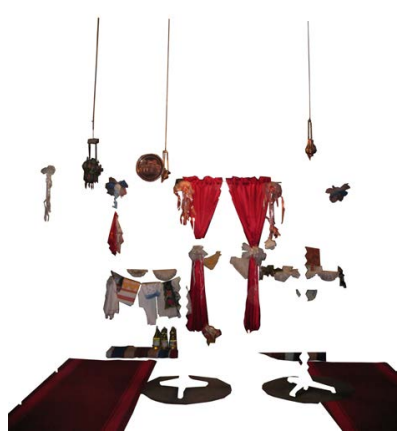

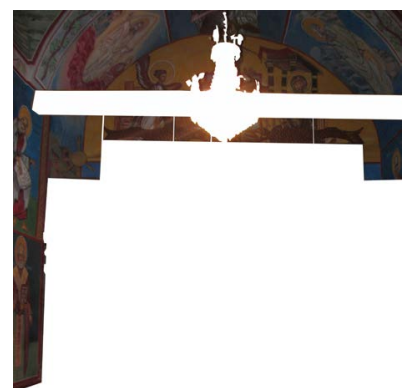

Fig. 3 Space-time layers of the church interior during the Day of the Holy Mother ceremony illustrating the overlap between ritual, ornament, surface, wall, space and structure. Church of the Holy Mother, Zavoj, Republic of Macedonia [Photo: Author, 2005; technical assistance Jose Rodriguez, 2014] 
The sensibility of distributing spatial volume via two-dimensional planes is assisted by inverse perspective. In inverse perspective, the lines of projection intersect technically outside and in front of the picture plane, in contrast to the point of intersection somewhere deep within the picture plane of Western perspective. From the point of the viewer looking at an icon, the pictorial space unfolds with breadth and immensity, effectively precluding penetration and preserving attention on the surface of the picture plane. This produces a spatially affective realm. A lack of realism further supports the iconographic intent to preserve the mysticism of the faith and the idea that transcendence and contact occur through the irrational, rather than through human logic (Ouspensky 1952: 40; Serafimova 1989: 110). For the non-religious but architecturally attuned observer, the continuity of the iconographic surface contrasts with the division of space. The iconostas, crafted as a screen of thin wood panelling rather than a solid wall, divides the sanctuary/altar from the central space. Continuity of the pictorial program on the walls and ceiling beyond this screen ties the sanctuary visually and narratively to the central domed space, contributing to atmosphere and affect, rather than geometric shape or spatial division. Like layers of enfolded fabric, these aspects of Byzantine tradition, articulated and translated in the small and otherwise insignificant church in Zavoj, represent architecture as the scene of plenitude, atmosphere and mystery - even prior to the movements of the congregation.

\section{Drawing, representation and affect}

Architectural drawings - plan and elevations - tell us the Church of the Holy Mother in Zavoj is a simple and small rectangular structure. Their meaning is associated with a familiar knowledge about vernacular architecture, imagined as a white, cubic object in the landscape. This orients, if not determines, meaning towards an understanding of architecture as formal or stylistic. Following Ingraham's (1991) exploration of the line, as not merely graphic representation but a way of thinking in architecture, this section explores how line drawing imparts particular conceptual frameworks and perception in architecture.

Line drawing and descriptive text both emphasise particular aspects of a scene and therefore provide only partial understanding. In the line drawings of the Zavoj church, the familiar effect of legitimate architectural representation induces a type of pleasure that is integral to being an architect. In acquiring the normative subjectivity of an architect (Evans 1997; Luscombe 1992), drawings play a central role (Robbins 1994), just as subjectivation in the Zavoj congregation involves learning the ritual traditions practiced within the church. Both these types of subjectivation involve "sensory impressions" and aspects of (dis)pleasure, and the "scene takes shape step by step through alternating and mutually constitutive interactions between changing and unchanging modes of experiences" (Lorenzer, in Olesen \& Weber 2013: 40). Pleasure, for architects, evolves through their developing relation to drawings, the capacity to read them ever more 'deeply', to let them access one's imagination, in turn, and impart meaning to one's worldview (Frascari 2011). A capacity to extract meaning from architectural drawings is considered a sophisticated skill in the architectural community and provides pleasure (Frascari 2011). Yet conventional drawings elide the way Byzantine architectural traditions blur the boundaries between ornament, surface and geometry.
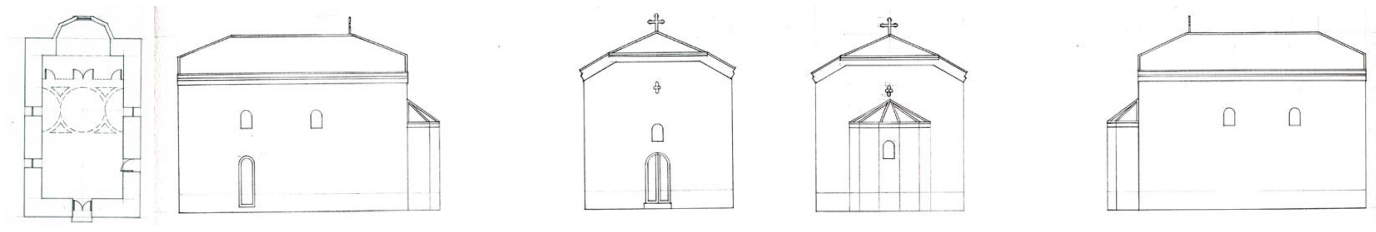

Fig. 4 The elegant simplicity of architectural drawings. Plan and elevations of the Church of the Holy Mother, Zavoj, Republic of Macedonia. [Drawings: Author \& Lee-Anne Manski, 2005] 
The rich and strange atmosphere of the interior, presented in the descriptive text and photographs, and the architecture in the sparse and linear depiction of the drawings represent the same entity, yet offer very different perceptions. In the difference between them, it becomes evident that the representation of the scene of the church can be neither a "factual account", nor "a transparent subjective expression” (Olesen \& Weber 2013: 33). Rather, it involves multiple layers of different texts or inscriptions. Descriptions of sounds, scents, rituals and histories can imprint an atmosphere on the line drawings. Conversely, it is possible that the line drawings make the mesmerising atmosphere more digestible, understandable, and perceivable. Affect and effect play out between the textual re-presentation of ritual, atmosphere and sensuality, and the line drawings of the church - as each mediates observation and experience differently.

Sensual movements intertwine with the structure, form and composition of the church architecture's set geometry and order. The interior becomes a place of plenitude, a fully sensory and sensual space, literally touched and moved by the spatial effects of the women's and priest's practices. It is as though from the carved, gilded and frescoed surfaces emerge textures, aromas, sounds, and tastes. As if the interior surfaces could no longer sustain their own ornamental energies, they burst forth in experiential relief (Lozanovska 2006: 323-330).

Lefebvre argues that the notion of "a container waiting to be filled by content" reflects an abstracted and "indifferent" relation between space and form (1991: 170). He points to the capacity of action and various corporeal energies to create space in an immediate sense. Each living body is space and has its space: it produces itself in space and it also produces that space. The spatial body, beyond the finite borders of the physical human body, includes the body's movement in and through space. Human bodies in relation to buildings constantly produce corporeal and temporal dimensions of architectural meaning that are chronically neglected when thinking about architecture in terms of static, three-dimensional forms. Like atmosphere, then, Lefebvre's spatiality is the medium between human bodies and objects. Through it, complex textures (e.g., of rituals, structure, volume, plane, surface, ornament and bodily activity) are temporarily woven, entangled, and can be unfolded as representation. Spatiality, thus, is not equivalent to space as volume. Rather, it can be perceived in the density of Marey's photographs of movement, which demonstrate that "no space ever vanishes utterly, leaving no trace" (1991:164). Manifestations of the body's movement in architectural space are constitutive, not an additional dimension, of space. The movements of bodies, incense and candle light, and their interactions with the building's materiality, re-present a complicated and dense scene: the women merge with the ornament and the interior space of the church, matter and air, and become part of its aesthetic condition (Irigaray 1985, 1992).

\section{Re-presentation as interpretive process}

Like annotations on the margins of drawings, fragments of descriptive text provide specificity and detail that can animate static images and transpose them towards imaginary movements and activities (Fig. 5). Re-presentation, like Silverman's visual-as-guide (1996) and Lorenzer's social imagination (Lorenzer in Olesen \& Weber 2013: 31-33), offers a way of looking again and can assist in negotiating manifest and other meanings. Space-time layers (Fig. 3) operative in the interior or the subjective perception of objective structures (Fig. 8) can be addressed. In consideration of these animations, I experimented with three different types of representation to address the rituals during the Day of the Holy Mother celebrations: an axonometric diagram sketch, a translucent physical model, and an unfolded elevation. These produce fragments of a scenic understanding of architecture as performative space, and raise questions about the interpretive process within representation. 

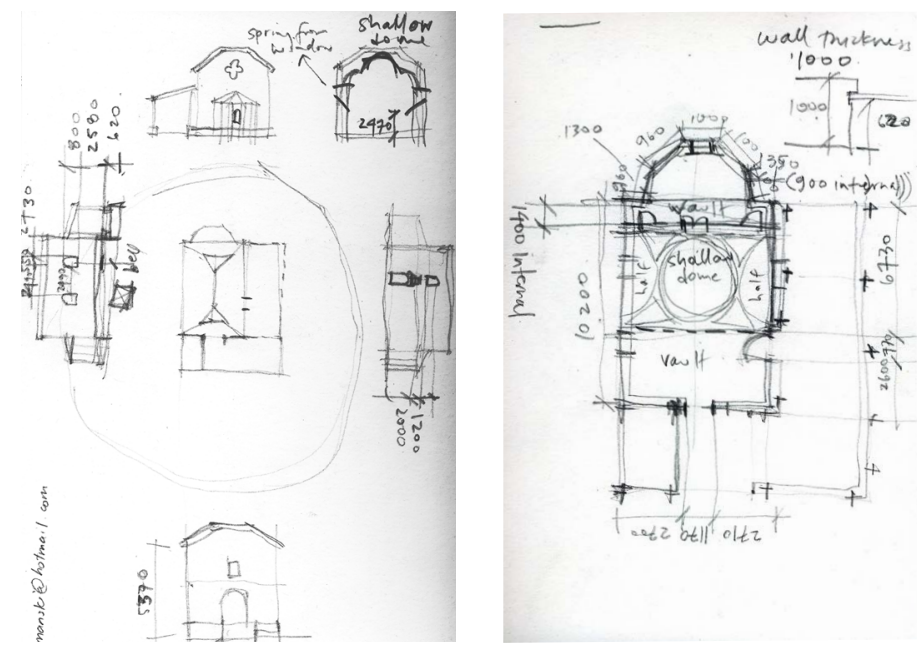

Fig. 5 Annotated sketch drawings and measurements. Church of the Holy Mother, Zavoj, Republic of Macedonia. [Author, 2005]

Rather than executing refined or methodologically extensive methods of representation, the intention here was to identify, in the everyday practices of architecture, accessible and immediate tools for rethinking representation. First, a quick diagrammatic axonometric sketch (Fig. 6) captures the paths of movement, activity, and ritual that co-exist with the interior's surface ornamentation, spatial axes, volume, and boundaries. This rough notation visually translates the observation and the descriptive text, and provides a spatial representation of the scene inside the church. This is not unlike the drawings that architects sketch on site, the details of which are often erased as the documentation is formalised into architectural plan and elevations. By deploying axonometric conventions, the drawing gives visibility to interior and external form simultaneously, as well as to representations of subjects and objects.

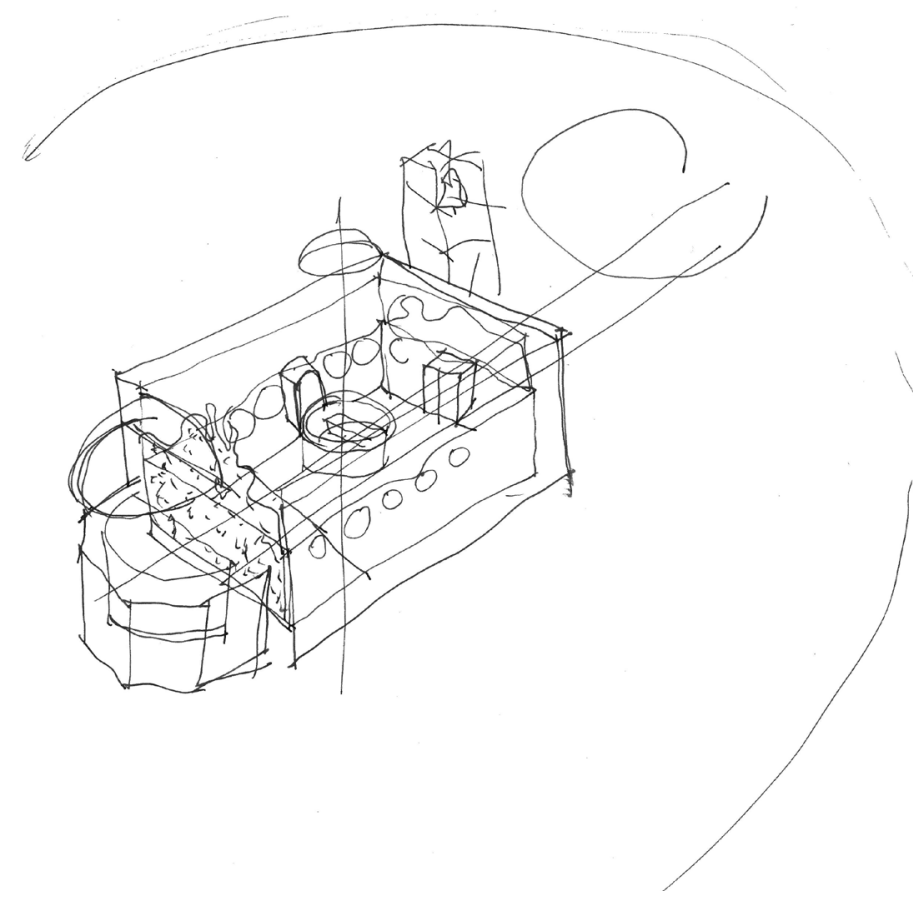

Fig. 6 Axonometric sketch illustrating the bodily ritual in relation to the pictorial surface and Byzantine interior, of the Church of the Holy Mother, Zavoj, Republic of Macedonia, 2005. [Drawing, Author, 2013] 
Then, I assembled a model of acetate sheets and slightly whitish Perspex sheets, as a way to perceive and reconstruct the scene of the church interior. The tension between two-dimensional and three-dimensional aspects of the scene was addressed through inscription: first, the drafted elevations and plan were printed onto the external walls of the model, producing a pictorial rather than proportional effect. Secondly, fragments of the interior wall elevations were inscribed onto the model's interior walls. Taken from a series of single viewpoints, the composite visual impression was intended to capture a way of looking in movement. These materials and methods were to negotiate the relationship between atmospheric condition and the volume and shape of the church building, contrasting the definitive and formal clarity of cardboard model-making material. Aspects of individual and collective rituals were also inscribed onto acetate and deployed within the space of the church.

The theorist Robin Evans stated that architecture involves translation from (largely) a two-dimensional medium of ideas (drawings) into a three- (or four- or ten-) dimensional medium when it is built, and that dormant imagination is called upon to make orthogonal architectural projections (Evans 1997). This model tries to represent a multi-dimensional, affective atmosphere, and also to preserve the latent imagination inherent in orthogonal projection, by preventing the volumetric or formal from dominating the representation and by dispersing it through surface inscription (Fig. 7). As a result, the assemblage of measured exterior and pictorial interior surface fragments into an abstracted and layered approximation of interior space creating a parallel mode of representation.

Finally, the production of line-drawing elevations extended the axonometric diagram (see Figure 8). Their unfolded surfaces show, firstly, another aspect of how a three-dimensional volume is made from a two-dimensional plan. Evans argued that elevations produced by the projection of parallel lines towards a picture plane are the quintessential representation of architecture. Yet a very different picture emerges if, in their path, the parallel lines project subjects, icons, temporary artefacts, in addition to walls and fenestration onto the picture plane. Secondly, the unfolded elevations re-present bodies, movements, and every ephemeral item, as clearly as the architecture, resulting in a plane of linear plenitude compared to the elegant emptiness of the original elevations.

The on-site sketch, axonometric drawing, model, and elevation can then register affect as mediation between the cerebral and the sensual, between embodiment, experience and intellectual argument. Experiments in representation incorporating something of the affect of the observer's roving eye (Mainstone 1988: 17) invite a reader's experiential interaction with drawing and model, and an observer's reading of architecture.

\section{Conclusion: The pleasure of (vernacular) architecture}

Architects, more than scholars, talk about the experience of architecture, and how they are moved when entering a particular building, usually focussing on a very individual subject-object relationship between the architect and the architectural edifice (Moravansky 2010). However, the 'moved' dimension of architecture can also be a collective socio-cultural phenomenon, and this has been noted during architects' off-the-beaten-track travels, or by architectural (or anthropological) scholars in the study of vernacular architecture (Catalan 2012; Tosolini 2008). Experience and observation is always partial, contingent and inter-subjective (Biln 1997). My observation of the scene inside the church, while incorporating a social and cultural dimension, is based on ontology and experience, and lays no claims to objectivity. Yet, the architectural discipline itself is constructed through the stories of architects' travels and a taxonomy of examples derived from architectural field-work. Documents, both literary and empirical, are established while the architect/historian/ scholar is immersed in the field. Field-work is an integral practice in the discipline, but questions such as: what is observed? how is it documented? and what is the role of the architect/scholar's 


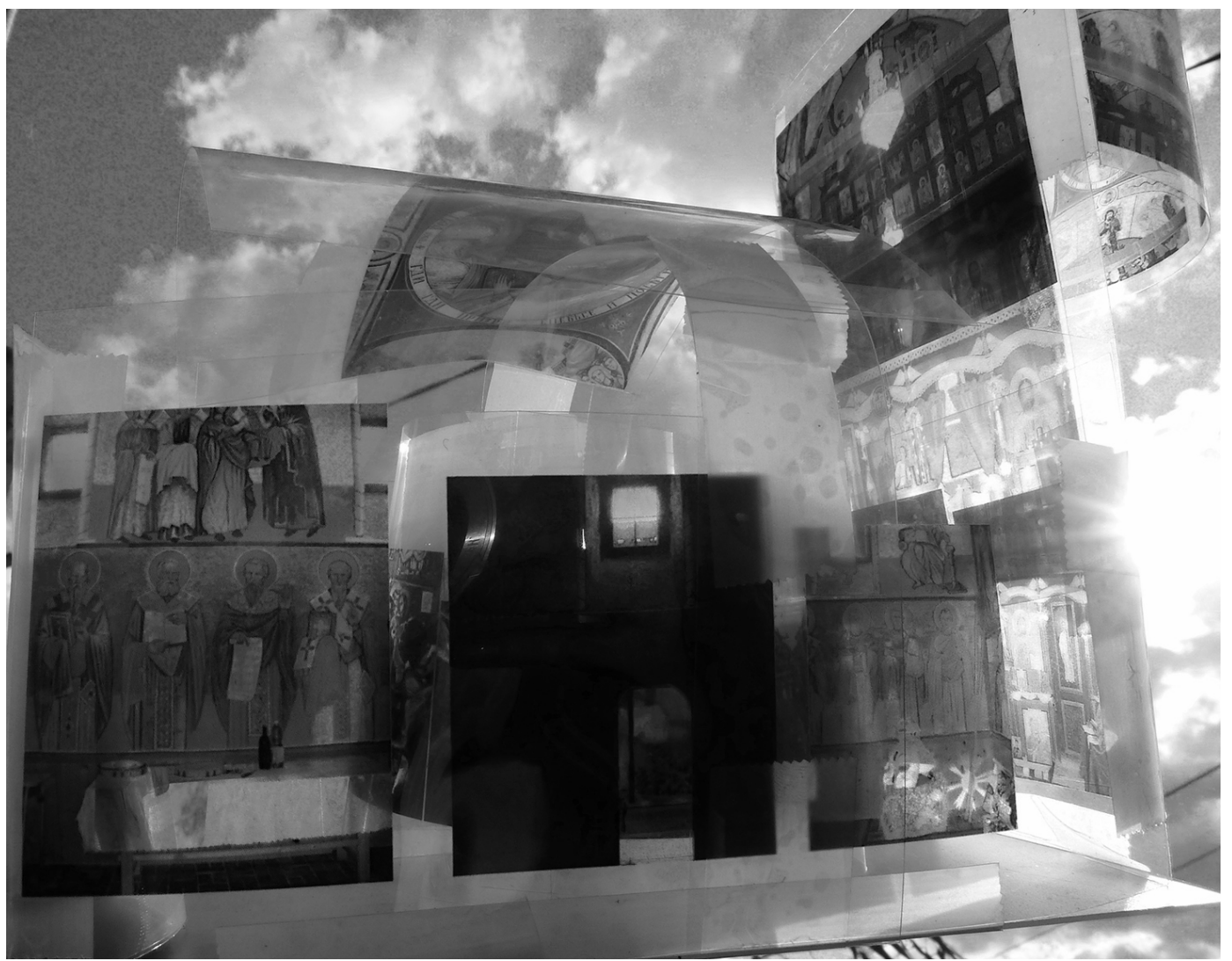

Fig. 7 Model illustrating the multiple layers of the scene. Church of the Holy Mother, Zavoj, Republic of Macedonia (2005) [Model and photograph, Author, 2013]

subjectivity? still provocatively ask "Who is moved?" in architecture.

Ideas of plenitude oppose conventional narratives of architecture that emphasise void and space as an empty transparent field. Inhabitations of space stir up such emptiness in sensory ways. In contrast to notions of user, function, and occupant, which incorporate the human body in architectural discourse, sensory inhabitation is difficult to measure and articulate. Sensibility of atmosphere or pleasure is provoked by observation, yet words, drawings, and their codes and contexts of meaning frame our sensibility of pleasure and the possibility of pleasure. The line drawing, important as the discipline's readable reference, articulates space as geometry, form, structure and establishes the object and void as separate fields. The descriptive text, photographs, and prior stories, present spatiality related to embodied movements (that is, ritualised architecture) of the interior. In my experiments, to look again at the role of visual conventions in architecture provided a way to mediate mainstream architecture with ritualised architecture. The scene is multi-layered, as Lorenzer notes; to construct a dual scene provides for a different perception and may offer insight into less apparent, collective unconscious meaning. Through the dual scene, the discipline looks at its own parameters and tools for looking at the scene.

Pleasure and observation are not new categories for the study or appreciation of vernacular architecture, but they are rarely deployed towards a rethinking of contemporary theory in architecture. Yet, in light of the mediating role of language (in addition to the canonical processes of the discipline), it is important to revise the enunciative position of the observer, and critically reflect on the roles of subject and object in viewing architecture. In combination with experimental 
representations, a psychoanalytic reading of the church atmosphere in the village of Zavoj during the Day of the Holy Mother shifts the pleasure of tradition from the blurred moved-ness of others or the pleasure of the writer and may thus affect the reader's worldview.

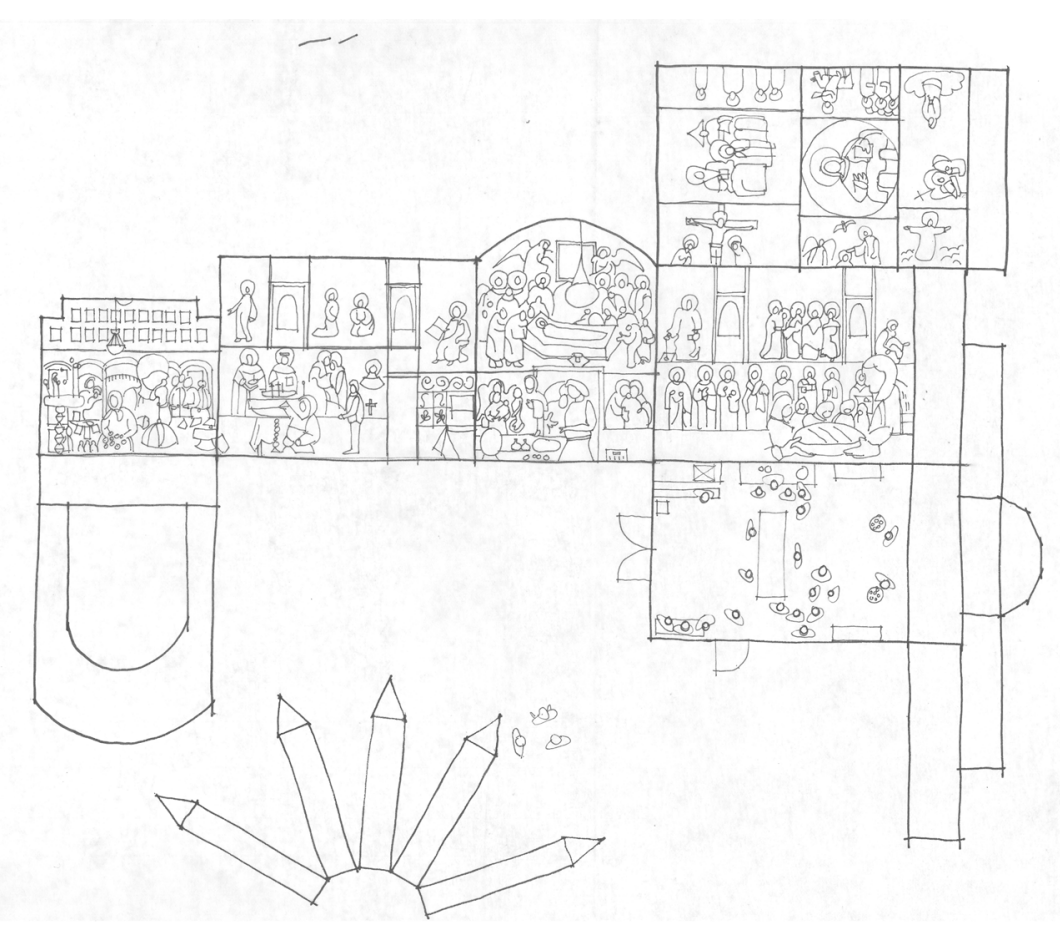

Fig. 8 Fold out elevation drawing of the interior of the Church of the Holy Mother, Zavoj, Republic of Macedonia, 2005. [Data, Author, 2005; drawing technical assistance Alexandra Anda Florea and Jose Rodriguez, 2014] 


\section{References}

Aipatov, M. V. (1978). Early Russian icon painting, (N. Johnstone, Trans.). Moscow, Russia: Iskusstvo. Barthes, R. (1975). The pleasure of the text (R. Miller, Trans.). New York, NY: Hill and Wang. Biln, J. (1997). (De)forming self and other: Toward an ethics of distance.(pp. 25-37). In B. Nalbantoglu and W. C. Thai (Eds,). Postcolonial space(s). 25-37. New York, NY: Princeton Architectural Press, .

Böhme, G. (2014). The Theory of armospheres and its applications, (A,-Chr. Engels Schwarzpaul Trans.). Interstices $15,92-99$

Butler, J. (1993). Bodies that matter: On the discursive limits of 'sex'. New York, NY: Routledge.

Butler, J. (2004). Undoing gender. New York, NY: Routledge.

Butler, J. (2009). Performative preclarity and sexual politics. AIBR: Revista de Antroplogia Iberoamericana 4 (3): 321-336. Retrieved from http://www.aibr.org/antropologia/04v03/criticos/040301b.pdf

Catalan, R. P. (2012). Le Corbusier, an architect on the way to the east: Impressions and drawings. Studia Universitatis Petru Maior-Philologia, 13.

Corbusier, Le, \& Žaknić, I. (2007). Journey to the east (I. Žaknić (Ed.). (I. Žaknić with J. Gery and N. Pertuiset, Trans.). Cambridge, MA: MIT Press.

Demus, O. (1970). Byzantine art and the west. New York, NY: New York University Press.

Demus, O. (1955). Byzantine mosaic decoration: Aspects of monumental art in Byzantium. Boston, MA: Boston Book and Art Shop.

Evans, R. (1986). Translations from drawing to building. Architecture Association Files, 12, 13-18.

Evans, R. (1997). Translations from drawing to building. Cambridge, MA: MIT Press.

Frascari, M. (2011). Eleven exercises in the art of architectural drawing: Slow food for the architect's imagination. London, UK: Routledge.

Ingraham, C. (1991). Lines and linearity: problems in architectural theory. In A. Kahn (Ed.), Drawing/building/text: Essays in architectural theory. (pp. 63-84) New York, NY: Princeton University Press.

Irigaray, L. (1985). This sex which is not one (C. Porter \& C. Burke, Trans.). Ithaca, NY: Cornell University Press.

Kostof, S. (1995). A history of architecture: Settings and rituals. New York, NY: Oxford University Press.

Lefebvre, H. (1991). The production of space (D. Nicholson-Smith, Trans.). Oxford, UK: Blackwell.

Lossky, V. (1952). Tradition and traditions. In L. Ouspensky \& V. Lossky (Eds.), The meaning of icons (G. E. H. Palmer \& E. Kadloubovsky, Trans.) (pp. 9-22). New York, NY: St. Vladimir's Seminary Press, Crestwood.

Lozanovska, M. (2010). Hagia Sofia, 532-537: A study of centrality, interiority and transcendence in architecture. The Journal of Architecture, 15(4), 425-448.

Lozanovska, M. (2006). Sveta Bogorodica (The Church of the Holy Mother), Zavoj, Macedonia: Writing about an insignificant vernacular building. In Contested terrains, proceedings of SAHANZ, 323-330.

Luscombe, D. \& Peden, A. (Eds.). (1992). Picturing architecture: Graphic presentation techniques in Australian architectural practice. Sydney, Australia: Craftsman House.

Mainstone, R. (1988). Hagia Sofia: Architecture structure and liturgy of Justinian's great church. London, UK: Thames and Hudson.

Mathews, T. F. (1999). Byzantium: From antiquity to the Renaissance. New York, NY: Abrams, 1998.

Moravánsky, Á (2010). My blue heaven: The architecture of atmosphere. Architecture Association Files, 61, $18-22$.

Olesen, H. S. \& Weber, K. (2013). Socialization, language, and scenic understanding: Alfred Lorenzer's contribution to psycho-societal methodology. Historical Social-Research, 38(2), 26-55.

Ouspensky, L. (1989/1952). The meaning and landscape of icons. In L. Ouspensky \& V. Lossky, (Eds.). The meaning of icons (G. E. H. Palmer \& E. Kadloubovsky, Trans.) (pp. 23-50). New York, NY: St. Vladimir's Seminary Press,

Crestwood.

Robbins, E. (1994). Why architects draw. Cambridge, MA: MIT Press.

Semper, G. (1989). The four elements of architecture and other writings (H. F. Mallgrave and W. Herrmann, Trans.). Cambridge,England: Cambridge University Press.

Serafimova, A. (1995). The middle ages. In N. Čausidis \& L. Ugrinovska (Eds.), Macedonia: Cultural heritage. (pp. 90173). Skopje, Republic of Macedonia: Misla.

Silverman, K. (1996). The threshold of the visible world. New York, NY: Routledge.

Tosolini, P. (2008). Other itineraries: Modern architects on countryside roads. The Journal of Architecture, 13(4), 427-451. 


\section{Endnotes}

1. Lorenzer's approach adopts psychoanalytic clinical practice for the analysis of social and cultural phenomena, focusing, like Julia Kristeva and Luce Irigaray, on the psychoanalytic interpretation of literary texts. A scene is the multi-layered situation in which a conflict arises between unconscious desire and conscious, societal or normative subjectivity. Scenic understanding, holistically taking account not only of language but also of sensory impressions, experiences and interactions (Olesen \& Weber 2013: 40), is intended to overcome the tension between logical comprehension and empathy, or manifest meaning and other, not yet apparent or excluded meanings. In a series of experiments, this paper will also explore the scene as a multi-layered negotiation between observation and the manifest conventional architectural drawings.

2. During the first field trip in 1988 , the village was still permanently inhabited by mostly elderly peo-ple. Between 1996 and 2013 , the village was observably emptied of inhabitants. However, an emi-grant community returns annually for the festivities of the Day of the Holy Mother.

3. There is, however, a more complex gender division of spatial use; while the men congregate largely outside the church, the (male) priest is central and integral to the proceedings, as are the (male) iconographer painters.

4. This strategy brings the vernacular into the same playing field as high art and avoids predetermined frameworks for discussing vernacular architecture - predominantly site-specific and historical, rather than theoretical.

5. An Ohrid iconographer recently repainted some frescoes in the Zavoj church, and it is possible to identify differences of style and skill.

6. A detailed analysis of Byzantine architecture in relation to spatiality is presented in an essay on St. Sofia in Istanbul (Lozanovska 2010), 